\title{
Analysis of Influential Factors of Teaching Effect of Innovation and Entrepreneurship Practice in Comprehensive University Based on ISM
}

\author{
Zhenyu $\mathrm{Xu}^{1,2} *$ \\ 1. School of Public Management \\ Northwest University \\ 2. Postdoctoral Innovation Base \\ Xi'an Technology Resources Market \\ Xi'an, 710069, China
}

\author{
Jinping $\mathrm{Wu}$ \\ School of Public Management \\ Northwest University \\ Xi'an, 710069, China
}

\begin{abstract}
This paper determined 24 key influencing factors, and used the ISM method to construct a hierarchical structure model to analyze the progressive relationship of innovation and entrepreneurship practice teaching effect's influencing factors in a comprehensive university. It has found that: (1) orientation and training objectives of the school are the basic factors guiding the practice teaching activities of innovation and entrepreneurship, which directly affect and stimulate the resource support and process management of practice teaching; (2) resource support and process management obviously affect the improvement of students' abilities in entrepreneurship and innovation practice and their satisfaction. The results indicate that school orientation and training objectives should be based on students' specific situation and fully consider their practical needs. Meanwhile strengthening the investment of all kinds of education resources and optimizing the entire process of internship teaching are also necessary.
\end{abstract}

Keywords-Innovation and Entrepreneurship; Practical Teaching; Influencing Factors; Interpretation Structure Model (ISM)

\section{INTRODUCTION}

Innovation is the life gene integrated into the blood of the 21st century, and entrepreneurship is the inexhaustible power to promoting social development. In September 2014, Premier Li Keqiang proposed the concept of "mass entrepreneurship and innovation" for the first time at the BBS summer Davos in Switzerland, calling on the whole society to innovate actively. Innovation and entrepreneurship education is the extension and concrete implementation of the definition of entrepreneurship and innovation in the field of education. With the wise development vision and firm reform drive of the top leadership of China, it has penetrated into all aspects of current college education reform. Since then, the party and the state have

The Humanities and Social Sciences Research Youth Project of the Ministry of Education, "Research on Robust Scheduling of Emergency Response Tasks for Multi-agent Interaction” (Project Number: 19YJC630196).

Shaanxi Soft Science Research Project "Study on Service Satisfaction Evaluation of Science and Technology Resource Sharing Platform” (Project Number: 2019KRM113).

Shaanxi Provincial Education Department Special Scientific Research Project "Study on the optimization model of cross-domain emergency materials coordination scheduling - taking Shaanxi as an example” (Project Number: 15JK1750). attached great importance to the development of innovation and entrepreneurship education and successively issued relevant documents and policies to better guide and promote its education reform. In September 2018, the state council issued "Opinions on Promoting the High-quality Development of Innovation and Entrepreneurship and Creating an Upgraded Version of Mass Entrepreneurship and Innovation”, highlighting the importance and urgency of strengthening relevant education and training among university students. In March 2019, "The Notice of the General Office of the Ministry of Education on Doing a Good job in 2019 Construction of Demonstration Universities for Deepening Innovation and Entrepreneurship Education Reform” clearly made important instructions on "promoting innovation and entrepreneurship education reform at a higher, deeper and more critical link level, striving to create an upgraded version of innovation and entrepreneurship education". Under the guidance of "mass entrepreneurship and innovation”, many provinces and cities have organized various entrepreneurship and innovation activities through multiple channels. Colleges have also actively carried out practical exploration of entrepreneurship and innovation education. Under this background, how to adjust or reform the current education system and pattern more scientifically and effectively, clarify the influencing factors of innovation and entrepreneurship practice teaching effect, and closely link education with social needs is a serious question that every researcher committed to innovation and entrepreneurship education should think about.

\section{RESEARCH StATUS AT HOME AND ABROAD}

For a long time, there has been a consensus in the field of Western research: assessing the benefits and importance of entrepreneurship education is a difficult task. Colette believes that many entrepreneurial studies have failed to confirm this view: the completion of formal entrepreneurship initiatives and entrepreneurship management courses can increase the likelihood of individual entrepreneurship ${ }^{[1]}$. However, some scholars who are brave enough to explore have been still adhering to the scientific and rigorous spirit of research to carry out the unremitting exploration of the evaluation of entrepreneurship education in a multi-faceted and multi-angled manner. Hemant believes that the key to improving 
entrepreneurship education's quality lies in investigating which specific teaching influence factors can most effectively guide students' entrepreneurial behavior ${ }^{[2]}$. Scholars use a variety of research methods, such as Badariah's questionnaire survey ${ }^{[3]}$ to investigate the effectiveness of entrepreneurship courses in public universities in Malaysia, especially in North Malaysia. The results has shown that entrepreneurship courses offered by the University of North Malaysia are very effective in improving students' entrepreneurial skills. That is, the entrepreneurship education and training in universities can stimulate business skills. In addition, Barringer ${ }^{[4]}$, Fayolle ${ }^{[5]}$, Mueller $^{[6]}$, Packham ${ }^{[7]}$ measure and evaluate the improvement of entrepreneurship education to participants through the skills and better entrepreneurial attitudes of entrepreneurship courses.

In the domestic aspect, research scholars rationally analyze the significance of the evaluation of innovation and entrepreneurship education's effect and quality in Europe and the United States for China. For example, Wang Zhongkui and $\mathrm{Hu}$ Xiaotian have summarized the experience of undergraduate teaching quality performance evaluation in UK universities ${ }^{[8]}$. Li Zuozhang analyzes the practical significance of British education based on the British "Excellent Teaching Framework" and proposes its enlightenment on the improvement of domestic teaching quality ${ }^{[9]}$. In the construction of specific innovation and entrepreneurship teaching quality evaluation index system, according to each evaluation subject, Yan Mingming builds evaluation indicators from the school level (school philosophy, management system), teacher level (teacher team, curriculum system setting), student level (innovative entrepreneurship spirit, innovation and entrepreneurial ability, assessment results ${ }^{[10]}$. Combining the level, characteristics, objectives, content, structure of research-based innovation and business skills education in university, its quality evaluation system established by Feng
Yanfei, Tong Xiaoling ${ }^{[11]}$ is as following: university environment (soft environment, hard environment), faculty (teacher background, innovation and entrepreneurship capacity, innovation and entrepreneurship teaching abality), teaching links (course design, teaching methods), student evaluation (student background, student performance, student satisfaction), social reputation (social influence, external academic links, graduate evaluation).

\section{RESEARCH METHODS AND RESEARCH DESIGN}

\section{A. Research Methods}

The Interpretative Structural Model (ISM) was proposed by Professor JN Wolfer in the United States in 1973. The method mainly applies to solving the problems of the hierarchical structure of complex systems such as society and economy. The core idea is: (1) extract the key components of the problem through various technical methods such as questionnaires and interviews. (2) use the matrix, directed graph and other technical methods to analyze the elements and their mutual relations, and draw a multi-level hierarchical directed (MLHD) graph. (3) explain the MLHD graph to achieve the purpose of clarifying the overall structure and level of the problem and raising the degree of understanding. The basic working principle of ISM is shown in Fig. 1:

\section{B. Data Collection (Interpretation and Description of Indicators)}

On the basis of systematically combing the research literature related to innovation and entrepreneurship teaching, this study comprehensively considers the multi-dimensional influence factors such as student satisfaction, colleges and universities, and finally screens and determines the following 24 key indicators that affect the effect of innovation and entrepreneurship practice teaching.

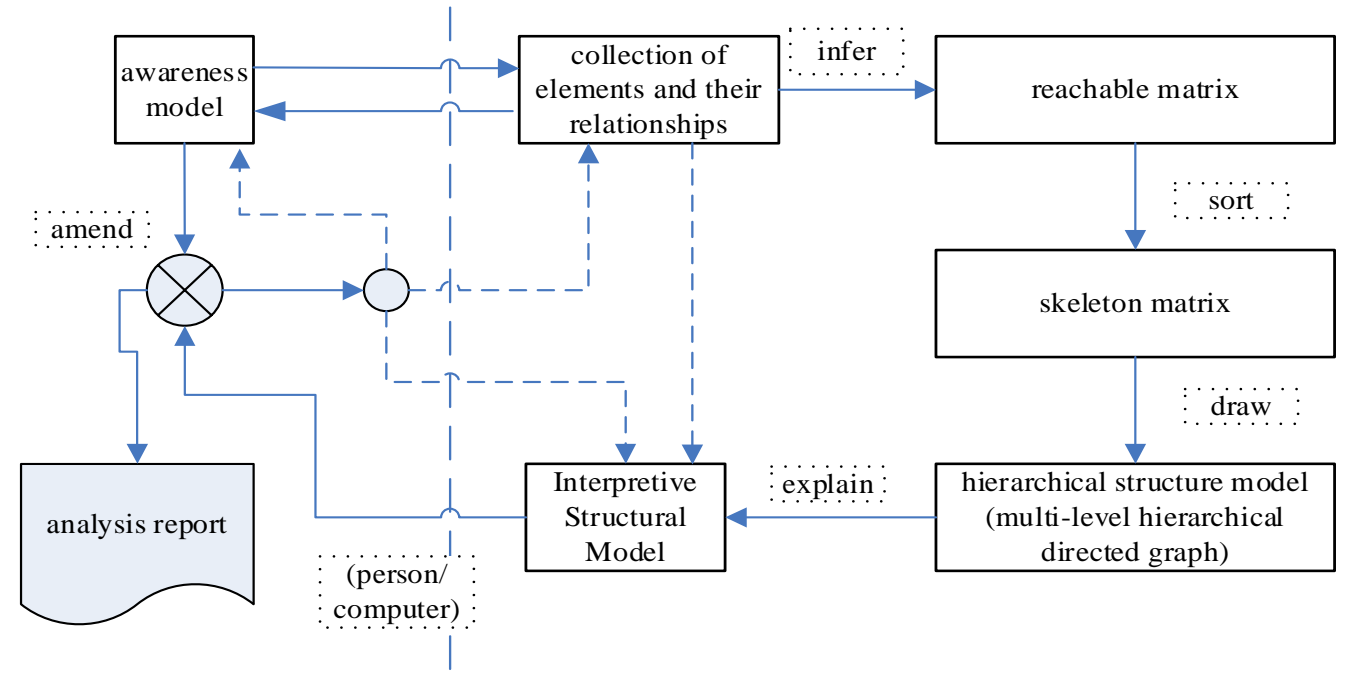

Fig. 1. ISM working principle diagram

TABLE I. KEY INDICATORS AND ITS CONNOTATION

\begin{tabular}{|c|c|}
\hline Indicator & Indicator connotation \\
\hline Satisfaction & A state of pleasure or disappointment that a student feels after comparing the expected education and teaching with the actual \\
education and teaching services & .12]
\end{tabular}




\begin{tabular}{|c|c|}
\hline \multicolumn{2}{|r|}{ Cont. to TABLE I. } \\
\hline $\begin{array}{c}\text { Entrepreneurial } \\
\text { potential }\end{array}$ & The potential for entrepreneurship which is not realized. \\
\hline $\begin{array}{c}\text { Scientific research } \\
\text { potential }\end{array}$ & $\begin{array}{c}\begin{array}{c}\text { The potential capabilities and strengths of an organization's scientific research activities, or a certain trend of research activities at } \\
\text { different time periods. }\end{array}\end{array}$ \\
\hline Social evaluation & $\begin{array}{c}\begin{array}{c}\text { The socially relevant departments organize social organizations and relevant persons to participate in the evaluation of a certain project } \\
\text { and matter according to certain social demand criteria. }\end{array}\end{array}$ \\
\hline Interpersonal ability & The ability to properly handle the relationship between peoples. \\
\hline Practical ability & The practical ability of students to apply theory to practice. \\
\hline Innovative ability & $\begin{array}{c}\text { The ability to propose existing ideas and materials to improve or create new things and achieve certain beneficial effects in a specific } \\
\text { environment }{ }^{[13]} \text {. }\end{array}$ \\
\hline $\begin{array}{l}\text { Scientific research } \\
\text { ability }\end{array}$ & The ability of scientific research personnel to solve problems through research, academic exchanges, and research projects. \\
\hline Professional interest & A positive cognitive tendency and interest of learners in a field of expertise. \\
\hline Professional knowledge & A relatively stable and systematic knowledge within a certain scope. \\
\hline Management ability & The comprehensive capabilities of planning, decision making, execution, monitoring, and evaluation around a specific project ${ }^{[14]}$. \\
\hline Internship management & $\begin{array}{c}\text { The process of carrying out planned and targeted scientific management of interns in the entire educational internship course according } \\
\text { to the professional nature of the internship discipline. }\end{array}$ \\
\hline Supervisory assessment & $\begin{array}{l}\text { The statistics, analysis and evaluation of the completion of the tasks performed by the leaders on the management personnel to ensure } \\
\text { that each job is correct }{ }^{[15]} \text {. }\end{array}$ \\
\hline Guidance level & Direct and indirect guidance that individuals receive during workplace learning. \\
\hline Internship method & The innovative entrepreneurship education internship method designed under the guidance of certain educational theories. \\
\hline Task content & The learning content in a task and project. \\
\hline Expenditure & The expenditures for the innovation and entrepreneurship education in colleges and universities. \\
\hline Internship base & A relatively large-scale and relatively stable internship and social practice venue. \\
\hline Faculty & The organic combination of all kinds of specialized talents that can be fully utilized by colleges and universities ${ }^{[16]}$. \\
\hline Teacher structure & The proportional relationship of each part of the teacher team and its structure. \\
\hline Internship plan & It includes the content of each internship, the planning and the budget of the internship. \\
\hline School orientation & The overall goal and direction of school development in a long historical period ${ }^{[17]}$. \\
\hline Training objectives & The specifications and standards that the training subject must achieve. \\
\hline
\end{tabular}

\section{Matrix Analysis and Model Establishment}

The establishment of the adjacency matrix of the factors influencing innovation and entrepreneurship practice teaching's effect is the basis of the explanatory structure model construction. Its role is to clarify the causal link between the elements. The specific definition is as below: the set of influencing factors is:

$$
\mathrm{S}=\left\{\mathrm{S}_{\mathrm{i}} \mid \mathrm{i}=1, \ldots \ldots, \mathrm{n}\right\}
$$

The adjacency matrix is a square matrix that represents the direct contact of the features. $A=\left(a_{i j}\right)_{n \times n}$ is specifically defined as follows:

$$
a_{i j}=\left\{\begin{array}{c}
1, i \neq j, S_{i} \text { affects } S_{j} \\
0, i \neq j, S_{i} \text { has no effect on } S_{j}
\end{array}\right.
$$

Through the investigation of five professors in the practice of teaching practice, three entrepreneurial intermediaries heads, and 32 students who participated in the innovation and entrepreneurship teaching, combined with the relevant literature research, the adjacency matrix of the factors influencing the teaching effect of innovation and entrepreneurship practice is as TABLE II.

TABLE II. ASYMPTOTIC MATRIX OF INFLUENCING FACTORS

\begin{tabular}{|c|c|c|c|c|c|c|c|c|c|c|c|c|c|c|c|c|c|c|c|c|c|c|c|c|}
\hline & $\mathrm{S}_{1}$ & $\mathrm{~S}_{2}$ & $\mathrm{~S}_{3}$ & $\mathrm{~S}_{4}$ & $\mathrm{~S}_{5}$ & $\mathrm{~S}_{6}$ & $\mathrm{~S}_{7}$ & $\mathrm{~S}_{8}$ & $\mathrm{~S}_{9}$ & $\mathrm{~S}_{10}$ & $\mathrm{~S}_{11}$ & $\mathrm{~S}_{12}$ & $\mathrm{~S}_{13}$ & $\mathrm{~S}_{14}$ & $\mathrm{~S}_{15}$ & $\mathrm{~S}_{16}$ & $\mathrm{~S}_{17}$ & $\mathrm{~S}_{18}$ & $\mathrm{~S}_{19}$ & $\mathrm{~S}_{20}$ & $\mathrm{~S}_{21}$ & $\mathrm{~S}_{22}$ & $\mathrm{~S}_{23}$ & $\mathrm{~S}_{24}$ \\
\hline $\mathrm{S}_{1}$ & 0 & 1 & 0 & 1 & 1 & 1 & 1 & 1 & 0 & 0 & 0 & 0 & 0 & 0 & 0 & 0 & 0 & 0 & 0 & 0 & 0 & 0 & 0 & 0 \\
\hline $\mathrm{S}_{2}$ & 1 & 0 & 0 & 1 & 1 & 1 & 1 & 1 & 0 & 0 & 0 & 0 & 0 & 0 & 0 & 0 & 0 & 0 & 0 & 0 & 0 & 0 & 0 & 0 \\
\hline $\mathrm{S}_{3}$ & 0 & 0 & 0 & 0 & 0 & 0 & 0 & 0 & 0 & 0 & 0 & 0 & 0 & 0 & 0 & 0 & 0 & 0 & 0 & 0 & 0 & 0 & 0 & 0 \\
\hline $\mathrm{S}_{4}$ & 0 & 0 & 0 & 0 & 0 & 0 & 0 & 0 & 0 & 0 & 0 & 0 & 0 & 0 & 0 & 0 & 0 & 0 & 0 & 0 & 0 & 0 & 0 & 0 \\
\hline $\mathrm{S}_{5}$ & 0 & 0 & 0 & 0 & 0 & 0 & 0 & 0 & 0 & 0 & 1 & 1 & 0 & 0 & 0 & 0 & 0 & 0 & 0 & 0 & 0 & 0 & 0 & 0 \\
\hline $\mathrm{S}_{6}$ & 0 & 0 & 0 & 0 & 0 & 0 & 0 & 0 & 0 & 0 & 0 & 0 & 1 & 0 & 0 & 0 & 0 & 0 & 0 & 0 & 0 & 0 & 0 & 0 \\
\hline $\mathrm{S}_{7}$ & 0 & 0 & 0 & 0 & 0 & 0 & 0 & 0 & 1 & 0 & 1 & 1 & 1 & 0 & 0 & 0 & 0 & 0 & 0 & 0 & 0 & 0 & 0 & 0 \\
\hline $\mathrm{S}_{8}$ & 0 & 0 & 0 & 0 & 0 & 0 & 0 & 0 & 1 & 1 & 0 & 0 & 0 & 0 & 0 & 0 & 0 & 0 & 0 & 0 & 0 & 0 & 0 & 0 \\
\hline $\mathrm{S}_{9}$ & 0 & 0 & 0 & 0 & 0 & 0 & 0 & 0 & 0 & 0 & 0 & 0 & 0 & 0 & 0 & 0 & 1 & 1 & 0 & 0 & 0 & 0 & 1 & 0 \\
\hline $\mathrm{S}_{10}$ & 0 & 0 & 0 & 0 & 0 & 0 & 0 & 0 & 0 & 0 & 0 & 0 & 0 & 1 & 1 & 0 & 0 & 1 & 0 & 0 & 0 & 0 & 1 & 0 \\
\hline $\mathrm{S}_{11}$ & 0 & 0 & 0 & 0 & 0 & 0 & 0 & 0 & 0 & 0 & 0 & 0 & 0 & 0 & 0 & 1 & 0 & 0 & 1 & 1 & 0 & 0 & 1 & 0 \\
\hline $\mathrm{S}_{12}$ & 0 & 0 & 0 & 0 & 0 & 0 & 0 & 0 & 0 & 0 & 0 & 0 & 0 & 0 & 0 & 1 & 0 & 0 & 1 & 0 & 0 & 0 & 0 & 0 \\
\hline $\mathrm{S}_{13}$ & 0 & 0 & 0 & 0 & 0 & 0 & 0 & 0 & 0 & 0 & 0 & 0 & 0 & 1 & 1 & 1 & 1 & 1 & 1 & 1 & 0 & 0 & 1 & 0 \\
\hline $\mathrm{S}_{14}$ & 0 & 0 & 0 & 0 & 0 & 0 & 0 & 0 & 0 & 0 & 0 & 0 & 0 & 0 & 0 & 0 & 0 & 0 & 0 & 0 & 1 & 1 & 0 & 0 \\
\hline
\end{tabular}




\begin{tabular}{|l|l|l|l|l|l|l|l|l|l|l|l|l|l|l|l|l|l|l|l|l|l|l|l|l|}
\hline \multicolumn{10}{|c|}{ Cont. to TABLE II. } \\
\hline $\mathrm{S}_{15}$ & 0 & 0 & 0 & 0 & 0 & 0 & 0 & 0 & 0 & 0 & 0 & 0 & 0 & 0 & 0 & 0 & 0 & 0 & 0 & 0 & 0 & 1 & 0 & 0 \\
\hline $\mathrm{S}_{16}$ & 0 & 0 & 0 & 0 & 0 & 0 & 0 & 0 & 0 & 0 & 0 & 0 & 0 & 0 & 0 & 0 & 0 & 0 & 0 & 0 & 1 & 0 & 0 & 0 \\
\hline $\mathrm{S}_{17}$ & 0 & 0 & 0 & 0 & 0 & 0 & 0 & 0 & 0 & 0 & 0 & 0 & 0 & 0 & 0 & 0 & 0 & 0 & 0 & 0 & 1 & 1 & 0 & 1 \\
\hline $\mathrm{S}_{18}$ & 0 & 0 & 0 & 0 & 0 & 0 & 0 & 0 & 0 & 0 & 0 & 0 & 0 & 0 & 0 & 0 & 0 & 0 & 0 & 0 & 0 & 1 & 0 & 0 \\
\hline $\mathrm{S}_{19}$ & 0 & 0 & 0 & 0 & 0 & 0 & 0 & 0 & 0 & 0 & 0 & 0 & 0 & 0 & 0 & 0 & 0 & 0 & 0 & 0 & 1 & 0 & 0 & 1 \\
\hline $\mathrm{S}_{20}$ & 0 & 0 & 0 & 0 & 0 & 0 & 0 & 0 & 0 & 0 & 0 & 0 & 0 & 0 & 0 & 0 & 0 & 0 & 0 & 0 & 1 & 0 & 0 & 1 \\
\hline $\mathrm{S}_{21}$ & 0 & 0 & 1 & 0 & 0 & 0 & 0 & 0 & 0 & 0 & 0 & 0 & 0 & 0 & 0 & 0 & 0 & 0 & 0 & 0 & 0 & 0 & 0 & 0 \\
\hline $\mathrm{S}_{22}$ & 0 & 0 & 1 & 0 & 0 & 0 & 0 & 0 & 0 & 0 & 0 & 0 & 0 & 0 & 0 & 0 & 0 & 0 & 0 & 0 & 0 & 0 & 0 & 0 \\
\hline $\mathrm{S}_{23}$ & 0 & 0 & 0 & 0 & 0 & 0 & 0 & 0 & 0 & 0 & 0 & 0 & 0 & 0 & 0 & 0 & 0 & 0 & 0 & 0 & 0 & 1 & 0 & 1 \\
\hline $\mathrm{S}_{24}$ & 0 & 0 & 1 & 0 & 0 & 0 & 0 & 0 & 0 & 0 & 0 & 0 & 0 & 0 & 0 & 0 & 0 & 0 & 0 & 0 & 0 & 0 & 0 & 0 \\
\hline
\end{tabular}

In order to perform location and hierarchy, the reachable matrix corresponding to the adjacency matrix is first calculated. The reachable matrix refers to the direct and indirect links between the factors affecting the matrix. There is a transitive binary relationship between $S_{i}$ and $S_{j}$, which means that $S_{i}$ can reach $S_{j}$.

The reachable matrix comprehensively expresses the direct and indirect connections in the matrix. Add the same-order unit matrix I to the adjacency matrix A according to the Boolean operation rule, and perform a power operation according to the Boolean algebra, namely: $\mathrm{M}=(\mathrm{A}+\mathrm{I})^{\mathrm{k}}=(\mathrm{A}+\mathrm{I})^{\mathrm{k}-1} \neq(\mathrm{A}+\mathrm{I})^{\mathrm{k}-2} \neq \ldots$ $\neq(A+I),(k \leqslant n-1)$. From the reachable matrix, the reachable set, the first set and the common set of the elements are further analyzed, and the location division and the hierarchical division are carried out. The result is the MLHD graph of the influencing factors of the innovation and entrepreneurship practice teaching effect which is as shown in Fig. 2.

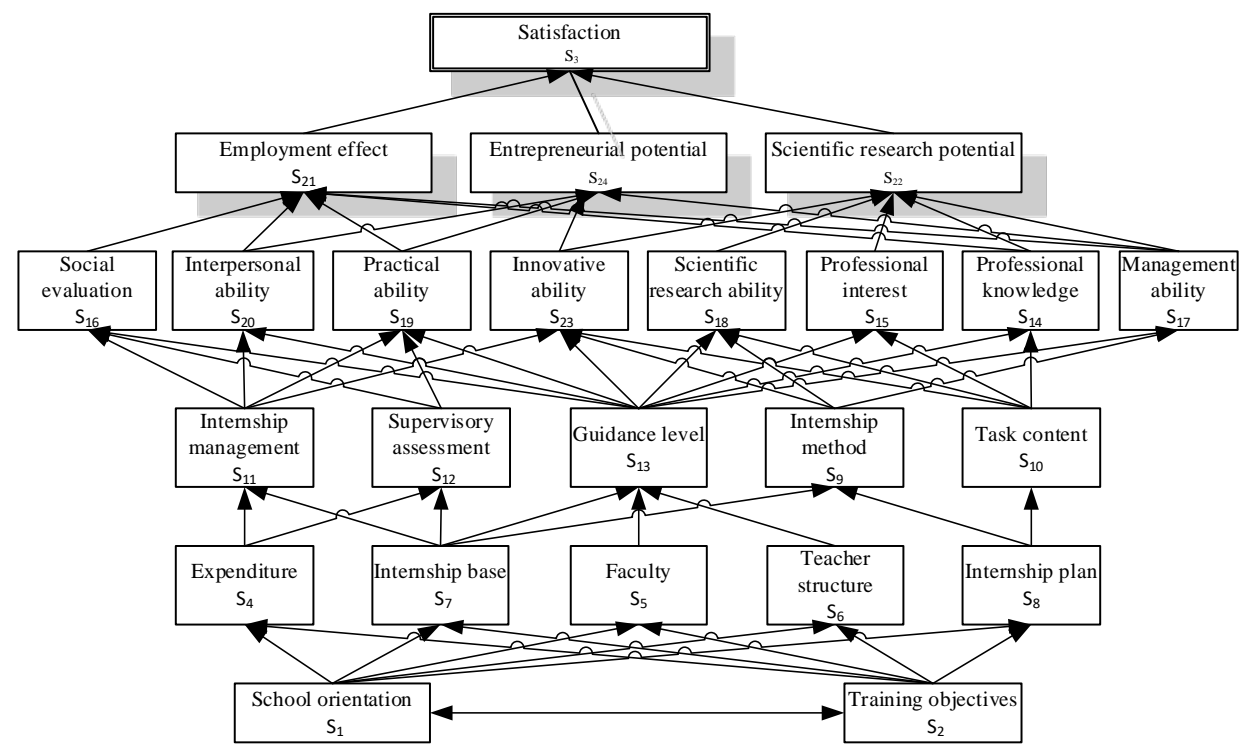

Fig. 2. Innovative entrepreneurial practice teaching effect influencing factors multi-level hierarchical directed graph

\section{ANALYSIS OF RESULTS}

Combined with the above analysis and research results, the main factors influencing students' satisfaction with innovation and entrepreneurship practice are presented in a five-level multi-level hierarchical structure (as shown in Fig. 1): These factors, basic elements, resource support elements, process management elements, capacity improvement elements and satisfaction show significant differences between the levels of the perceptual elements. Among them, the orientation and training goal of the school are the macroscopic factors that affect the satisfaction of students' innovation and entrepreneurship practice teaching, which mainly play a basic guiding role. The development orientation of the school has an important impact on the overall humanistic quality of teachers and students, thus establishing a reasonable school mechanism and campus environment is critical. It directly influences the students' satisfaction of business skills education . Therefore, the school orientation and training objectives should be student-centered, fully consider the students' practical needs, and improve their ability to innovate and start their own business as the core goal of teaching and educating people. In addition, the necessary supporting elements such as school investment in innovative internships, construction of internship base, teacher structure, and internship plan have a micro-impact on the students' satisfaction, and further influences the internship management, supervision and assessment, guidance level, task content and other specific teaching guidance. The teaching and guidance work will directly serve the mastery of students' professional knowledge and the cultivation of professional interests, as well as the interpersonal, practical, innovative, scientific, management and social evaluation of students. These will significantly affect the 
specific perceptual factors of student internship teaching satisfaction such as employment effect, entrepreneurial ability and scientific research potential.

It is not difficult to see that the practice teaching process is a closely related logical structure, and there are obvious progressive hierarchical structures among the influencing factors. Therefore, in the procedure of school innovation and business skills practice, the overall development direction should be grasped by guiding documents such as school positioning, training goal establishment firstly. Secondly, it should focus on infrastructure construction and resource investment such as hardware, funding, teachers, and scientific long-term and short-term internship planning. On this basis, it is necessary to attach great importance to standardizing and improving the internship management process and level, strengthen teachers and relevant management personnel's guidance and supervision and evaluation of teaching behaviors, enhance the level of teaching, and continuously promote the optimization and improvement of the internship methods and task content, paying attention to the comprehensive improvement and in-depth exploration of students' innovative capability. In the end, we will achieve good employment, entrepreneurship, and study, and truly implement the concept of "mass entrepreneurship and innovation" in the field of education, so that we can achieve a satisfactory education for the people.

\section{CONCLUSION}

Based on the existing literature, this study uses the explanatory structure model to mine and refine the influencing factors affecting students' innovation and entrepreneurial satisfaction, and systematically analyzes the hierarchical relationship between the influencing factors. The role of combining elements is summarized as follows: basic elements, resource supporting factors, process management elements, capacity improvement factors, and satisfaction perception factors. It explains the various levels of elements' role and function in the procedure of innovation and business skills practice teaching. However, due to the lack of quantitative supporting data, the mechanism and incentive of various factors playing a role cannot be studied in depth. In the future, relevant cases and historical data will be collected and sorted out to analyze and put forward conceptual models, and empirical and policy analysis will be conducted to enrich existing research results.

\section{REFERENCES}

[1] Colette H, Hill F, Leitch C. Entrepreneurship education and training: Can entrepreneurship be taught?[J].Education + Training, 2005, 47 (3):158-169.

[2] Hemant Kassean, Jeff Vanevenhoven, Eric Liguori, Doan E. Winkel. Entrepreneurship education: a need for reflection, real-world experience and action[J]. International Journal of Entrepreneurial Behavior \& Research, 2015, 21(5):690-708.

[3] Badariah Hj Din, Abdul Rahim Anuar, Mariana Usman. The Effectiveness of the Entrepreneurship Education Program in Upgrading Entrepreneurial Skills among Public University Students[J].Procedia-Social and Behavioral Sciences, 2016, 224:117-123.

[4] Barringer B, Jones F, Neubaum D. A quantitative content analysis of the characteristics of rapid-growth firms and their founders[J].Journal of Business Venturing, 2005, 20 :63-687.

[5] Fayolle A, Gailly B, Lassas-Clerc N. Assessing the impact of entrepreneurship education programmes: A new methodology[J].Journal of European Industrial Training, 2006, 30 (9) :701-720.

[6] Mueller S. Increasing entrepreneurial intention: Effective entrepreneurship course characteristics[J].International Journal of Entrepreneurship and Small Business, 2011, 13 (1):55-74.

[7] Packham G, Jones P, Miller C, et al. Attitudes towards entrepreneurship education: A comparative analysis[J].Education + Training, 2010, 52 (8-9):568-586.(In Chinese)

[8] Wang Zhongkui, Hu Xiaotian. Implementation path of undergraduate teaching quality performance evaluation: experience and inspiration from the UK [J]. Research on education development, 2008, 38(17):71-77+84. (In Chinese)

[9] Li Zuozhang, Liu Xuezhi, Jiang Wanchen. Standards-based evaluation of university teaching quality: UK experience and inspiration -evaluation and analysis of TEF [J]. Foreign education research, 2008, 45(06):55-66. (In Chinese)

[10] Yan Mingming. Research on evaluation index system of innovation and entrepreneurship education for local college students [J]. Journal of changchun institute of education, 2008, 34(09):28-31. (In Chinese)

[11] Feng Yanfei, Tong Xiaoling. Quality evaluation model and method of innovation and entrepreneurship education in research universities [J] Journal of huazhong agricultural university (social science edition), 2013(01):122-128. (In Chinese)

[12] Zhang Wei, Lin Jiabao. An Empirical Analysis of Factors Affecting University Teaching Satisfaction--Based on Students' Expectation and Students' Perceived Quality[J].Fudan Education Forum, 2014, 12(04):59-65. (In Chinese)

[13] Guan Wenchuan. Study on the Necessity of Implementing Interdisciplinary Project-based Learning in Primary and Middle Schools[J].Shanghai Curriculum Teaching Research, 2019(03):29-32. (In Chinese)

[14] Wu Chaoan. Research on the mechanism of social organization to promote labor employment [D]. Central China Normal University, 2013. (In Chinese)

[15] Zheng Xianbin. Study on Safety Management of Chemical Construction Enterprises[D].Southwest Jiaotong University, 2014. (In Chinese)

[16] Han Haibin. Research on the Convergence of Regional Higher Education Development in China [D]. Tianjin University, 2010. (In Chinese)

[17] Wang Xiaocun. Study on the Ideas and Mechanisms of Disciplinary Majors in Colleges and Universities[M]. Beijing: Science Press, 2008. (In Chinese) 